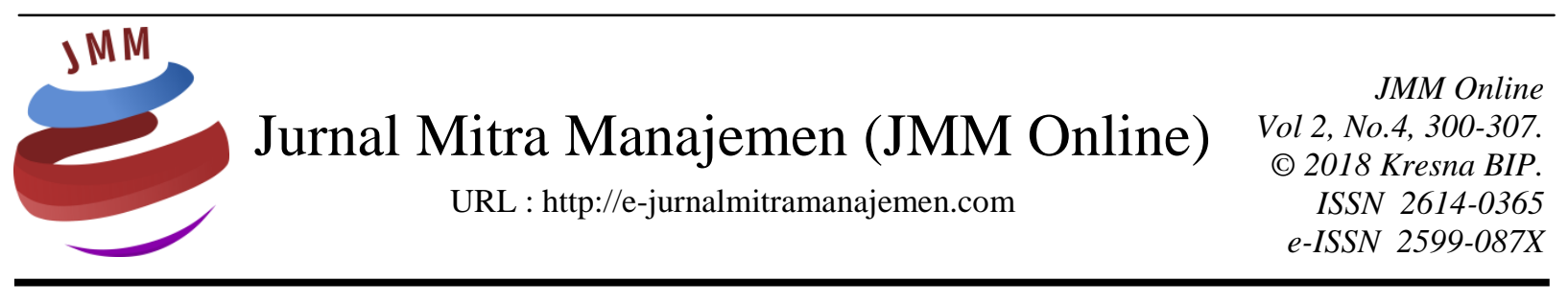

\title{
PENGOLAHAN DAN MANAJEMEN USAHA KELOMPOK MAWAR DAN DAHLIA UNTUK PANGAN ENBAL
}

\author{
Elizabeth Juleny Tapotubun ${ }^{1)}$, Bruri B. Tumiwa ${ }^{2)}$ \\ Politeknik Perikanan Negeri Tual
}

INFORMASI ARTIKEL

Dikirim : 28 Juni 2018

Revisi pertama : 16 Juli 2018

Diterima : 18 Juli 2018

Tersedia online : 28 Juli 2018

Kata Kunci : Ohoi Wain, Olahan enbal, Manajemen Usaha, Sejahtera

Email : elizabethjuleny.polikant@gmail.com

\section{ABSTRAK}

Tujuan penerapan ipteks bagi masyarakat ini merupakan salah satu jawaban bagi upaya mendorong dan meningkatkan minat usaha sebagai calon wirausaha baru yang dapat memberikan kontribusi untuk meningkatkan kesejahteraan masyarakat seperti kelompok usaha olahan enbal di Ohoi Wain Kecamatan Kei kecil. Tahap pendekatan, sosialisasi, pelaksanaan, evaluasi dan pendampingan kepada mitra kelompok olahan enbal merupakan langkah yang dilakukan sehingga luaran yang dihasilkan dari $I_{b} M$ ini yaitu dapat memberikan konstribusi yang baru dalam pengelolaan hasil perikanan di Kabupaten Maluku Tenggara serta organisasi usaha yang permanen dengan manajemen usaha yang baik, pembukuan yang baik, peralatan produksi yang memadai, peningkatan nilai estetika produk melalui pengemasan dan label yang baik dan menarik serta publikasi ilmiah. Tahapan kegiatan yang dilakukan dari kegiatan IbM ini yaitu tahap pendekatan awal dengan mitra, penyuluhan dan pelatihan manajemen usaha, sistem pengemasan, strategi pemasaran, pembuatan enbal ikan, pembuatan cap kelompok usaha, pendampingan serta pemberian bantuan peralatan pembuatan tepung ikan kepada kedua mitra. 


\section{PENDAHULUAN \\ Latar Belakang}

Ohoi Wain merupakan salah satu ohoi yang berada di pesisir Kecamatan kei kecil Kabupaten Maluku Tenggara dengan jumlah penduduk \pm 1.133 jiwa dengan mata pencaharian penduduk yang umumnya petani. Ohoi Wain selama ini juga seperti beberapa ohoi pesisir lainnya yang memiliki sumberdaya laut maupun sumberdaya pertanian khususnya enbal (dalam bahasa daerah 'Kei') atau lebih dikenal dengan ubi kayu atau singkong (bahasa 'Jawa') (Tapotubun 2012).

Meningkatnya kesadaran warga ohoi wain akan begitu besarnya manfaat yang didapat dengan bertani enbal karena permintaan terhadap enbal sangat besar, sehingga oleh pemerintah Ohoi Wain pada tahun 2012 membentuk GAPOKTAN (Gabungan Kelompok Tani) dengan nama Wain Raya Sejahtera yang memiliki 7 kelompok produksi enbal dan 16 kelompok pengolahan enbal. Kelompok -kelompok ini, oleh pemerintahan ohoi wain terus digenjot untuk memproduksi maupun mengolah enbal menjadi beraneka macam olahan seperti enbal polos (tidak ditambah apapun), enbal stik, dan enbal bunga namun masih di kemas dengan sangat sederhana serta nilai gizi yang sangat rendah, belum memiliki informasi nilai gizi dan masa simpan.

Potensi usaha enbal yang sangat besar ini kemudian oleh pemerintah Kabupaten Maluku Tenggara pada tahun 2014 memberikan bantuan 60 ha area untuk penanaman enbal kepada ohoi wain dan selanjutnya oleh pemerintah ohoi wain dilanjutkan kepada kelompok-kelompok produksi yang telah terbentuk. Bantuan yang di berikan tersebut merupakan tindak lanjut pemerintah kabupaten dalam mensukseskan salah satu tujuan dari RPJMD Kabupaten Maluku Tenggara untuk menyuarakan kepada masyarakat kembali mengkonsumsi pangan lokal enbal dengan salah satu programnya yaitu One Day No Rice. Seperti gayung bersambut oleh Dinas Pertanian Propinsi Maluku pada awal Tahun 2015 ini, ohoi wain juga mendapat bantuan 50 ha area untuk penan.aman enbal sehingga produksi enbal akan meningkat di Kabupaten Maluku Tenggara.

Berdasarkan hasil pengamatan dan analisa situasi terhadap kelompok usaha ini maka diperlukan suatu upaya stimulasi untuk meningkatkan pengetahuan dan ketrampilan kelompok usaha ini khususnya dalam manajemen usaha dan keuangan, penyediaan peralatan, ketrampilan produk olahan lain serta perluasan jaringan dan strategi pemasaran.

\section{Rumusan Masalah}

Berdasarkan latar belakang diatas, maka rumusan masalah pada penelitian ini sebagai berikut :

1. Bagaimanakah cara memberikan penyuluhan tentang manajemen usaha dan pengelolaan keuangan, strategi pemasaran, sistem pengemasan, proses pembuatan enbal ikan, pembuatan buku kas dan cap produksi?

2. Kepada siapa pemberian bantuan peralatan tepung ikan?

3. Bagaimanakah proses evaluasi dan pendampingan terhadap kelompok IbM ? 


\section{Tujuan Penelitian}

Tujuan dari pelaksanaan IbM ini yaitu :

1. Memberikan penyuluhan tentang manajemen usaha dan pengelolaan keuangan, strategi pemasaran, sistem pengemasan serta mempelajari proses pembuatan enbal ikan, pembuatan buku kas dan cap produksi.

2. Memberikan bantuan peralatan tepung ikan

3. Melakukan evaluasi dan pendampingan terhadap mitra IbM.

\section{KAJIAN PUSTAKA Manajemen Usaha}

Kelompok IbM Mawar dan Dahlia merupakan kelompok yang tergolong dalam kelompok usaha kecil menengah yang sangat berkembang dan sangat disuport oleh pemerintah untuk terus dikembangkan. Menurut Glendoh 2001, pemerintah telah mengatur pembinaan dan pengembangan usaha yang tertuang dalam undang-undang Republik Indonesia nomor 9 tahun 1995 dan ditindak lanjuti dalam Peraturan pemerintah Republik Indonesia nomor 32 tahun 1998. Pembinaan dan pengembangan manajemen usaha merupakan upaya yang dilakukan oleh pemerintah, dunia usaha dan masyarakat melalui pemberian bimbingan dan bantuan perkuatan untuk menumbuhkan dan meningkatkan kemampuan usaha kecil agar menjadi usaha yang tangguh dan mandiri serta dapat berkembang menjadi usaha menengah.

\section{Enbal Ikan}

Enbal merupakan makanan khas masyarakat Kepulauan Kei yang berasal dari singkong yang agak pahit, diperas airnya, diambil ampasnya dan dipres menggunakan alat press dengan bentuk bulat yang disebut dengan enbal lolun. Menurut Tapotubun dan Tumiwa (2015), proses pembuatan tepung enbal meliputi enbal lolun yang berukuran $\pm 3 \mathrm{Kg}$, kemudian dibelah dan dikeringkan dengan cara dijemur dan dianginanginkan \pm 1 jam. Enbal yang agak kering tersebut kemudian diayak dengan ayakan ukuran 70 mesh sehingga menghasilkan tepung enbal yang siap diolah.

Tepung ikan merupakan sumber gizi yang sangat baik bagi tubuh karena mengandung $78,62 \%$ protein, 2,64\% lemak dan berbagai komponen gizi lainnya (Tapotubun 2012). Tepung ikan dengan mutu yang tinggi mempunyai tekstur tepung ikan halus, bebas benda asing dan serangga, baunya khas tepung ikan, berwarna coklat kekuningan khas tepung ikan. Mutu tepung ikan dipengaruhi oleh beberapa faktor, yaitu bahan baku yang digunakan, metode pengolahan serta cara dan lama penyimpanan. Proses pembuatan yang semakin baik diharapkan dapat meningkatkan kualitas dan rendemen tepung yang dihasilkannya sehingga dapat meningkatkan dan memenuhi kebutuhan tepung ikan dalam negeri (Annafi 2009).

Enbal merupakan produk yang mengandung karbohidrat tinggi, namun nilai gizi lainnya sangat rendah sehingga untuk meningkatkan nilai gizi maka ditambahkan tepung ikan (Tapotubun 2012) dan tepung ikan dan sayur (Riry et all. 2018) dengan daya terima panelis konsentrasi $15 \%$ yang memberikan rasa yang enak dan gurih dengan tingkat kesukaan netral hingga suka (Riry et all. 2013). 


\section{METODE PENELITIAN}

\section{Waktu dan Tempat Penelitian}

Kegiatan Ipteks bagi Masyarakat (IbM) ini dilaksanakan pada tanggal 14 Juli 12 Oktober 2016 dan bertempat pada Ohoi Wain Kabupaten Maluku Tenggara.

\section{Metode}

- Tahap awal ( Pendekatan khalayak sasaran)

Pendekatan dilakukan kepada khalayak sasaran yaitu kelompok usaha enbal ikan untuk mengumpulkan informasi agar diketahui permasalahan yang dihadapi dan bersama-sama menganalisis prioritas pemecahan masalahnya.

- Tahap pelaksanaan

Tahap pelaksanaan terdiri dari :

- Sosialisasi program; ini dimaksudkan agar kelompok usaha mengetahui pelaksanaan IbM dan siap menerima kegiatan ini untuk meningkatkan usaha dan kesejahteraan karyawannya.

- Perlakuan;

a. Memberikan penyuluhan dan pelatihan manajemen usaha dan pengelolaan keuangan.

b. Memberikan bantuan peralatan yang diperlukan untuk proses produksi khususnya peralatan pembuatan tepung ikan dan alat pengemas vakum

c. Memberikan penyuluhan dan pelatihan tentang sistem pengemasan yang baik.

d. Memberikan pelatihan pembuatan enbal ikan yang berkualitas dengan menjaga sanitasi dan higienenya.

e. Memberikan penyuluhan tentang strategi pemasaran dan upaya memperluas jaringan pemasaran.

\section{Bahan dan Alat}

Bahan yang digunakan adalah ikan teri dan ikan layang segar dan beberapa bumbu-bumbu seperti sereh, jahe dan lengkuas. Peralatan yang digunakan untuk pembuatan tepung ikan yaitu: panci kukus, blender/molen, pisau, plastik Polyethylene (PE), timbangan, ayakan, oven, loyang almunium.

\section{Prosedur kerja:}

- Pembuatan Tepung Ikan

Pembuatan tepung ikan diawali dengan proses penimbangan ikan. Tahap selanjutnya dilakukan pencucian dengan air dingin untuk membuang kotoran, lendir dan benda-benda asing yang melekat pada tubuh ikan.

Ikan dibuat fillet kemudian dilumatkan dengan alat mollen. Langkah selanjutnya adalah daging ikan layang lumat dikukus dengan air yang mendidih selama 30 menit kemudian dikeringkan dengan oven. Daging lumat yang telah kering tersebut digiling dan diayak menggunakan ayakan ukuran 100 mesh hingga dihasilkan tepung ikan layang. Diagram alir tahapan pembuatan tepung ikan dapat dilihat pada Gambar 1. 


\section{Gambar 1 .Tahapan Pembuatan Tepung Ikan}

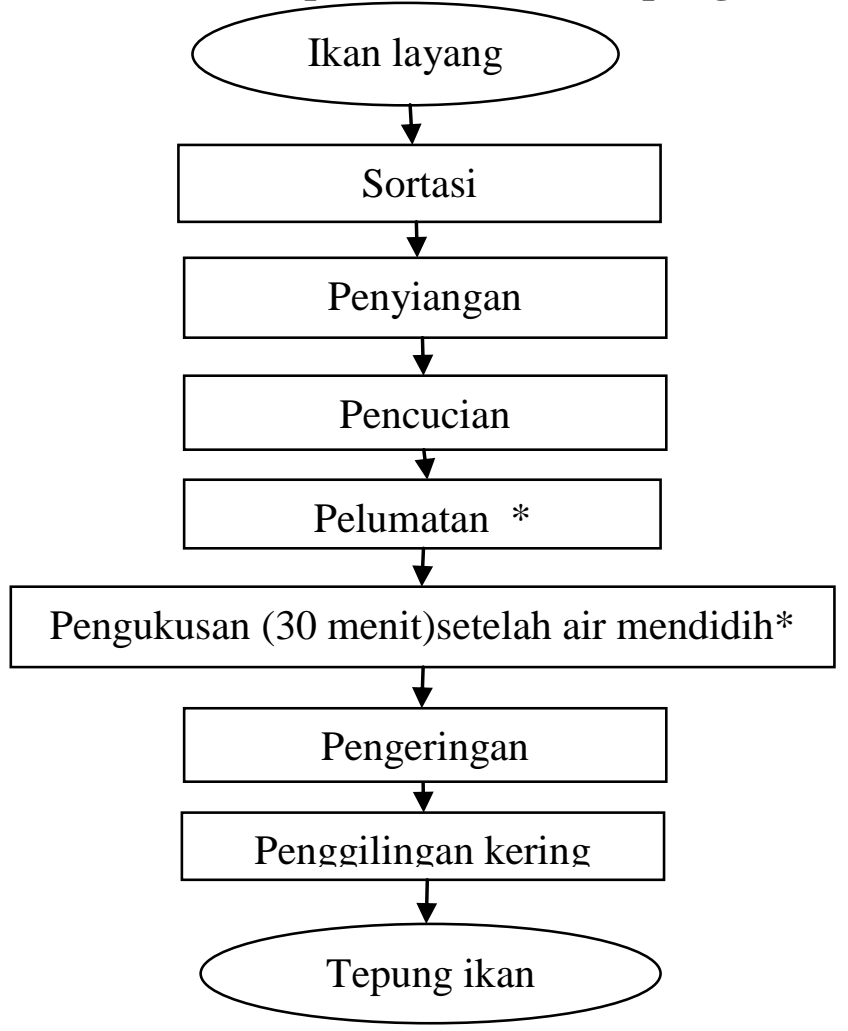

- Pembuatan Enbal

Sumber : Tapotubun (2012)

Pembuatan tepung enbal dilakukan menggunakan prosedur yang sering dilakukan oleh masyarakat setempat yang biasanya mengolah tepung enbal. Enbal lolun yang berbentuk bulatan kemudian dibelah-belah dan dijemur selama 4 jam di bawah sinar matahari. Enbal yang telah dijemur kemudian diayak dengan ayakan ukuran 70 mesh. Tahapan pembuatan tepung enbal dapat dilihat pada Gambar 2.

Gambar 2. Tahapan Pembuatan Tepung Enbal Cara Tradisional

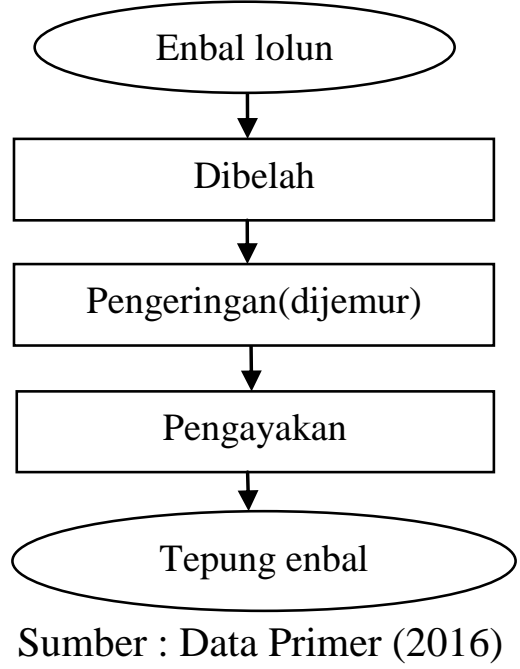


- Pembuatan Enbal Ikan

Tepung ikan dan tepung enbal yang telah siap kemudian di timbang dengan berat masing-masing untuk tepung ikan 150 gr dan tepung enbal 850 gr. Kedua tepung tersebut kemudian dicampur sampai homogen dan diletakan dalam cetakan yang terbuat dari alumunium. Cetakan yang telah berisi adonan tepung enbal dengan tepung ikan kemudian dibakar di atas tungku perapian selama \pm 10 menit dengan cetakan yang tertutup agar proses pembakaran berjalan sempurna dan adonan matang secara merata. Enbal ikan yang telah masak kemudian diambil dan dikeringkan menggunakan oven atau dijemur dibawah sinar matahari sampai produk benar-benar kering. Enbal ikan yang telah siap kemudian dikemas. Tahapan pembuatan enbal ikan layang pada penelitian ini dapat dilihat pada Gambar 3.

Gambar 3. Skema Metode Penelitian Pembuatan Enbal dengan Penambahan Tepung Ikan Layang

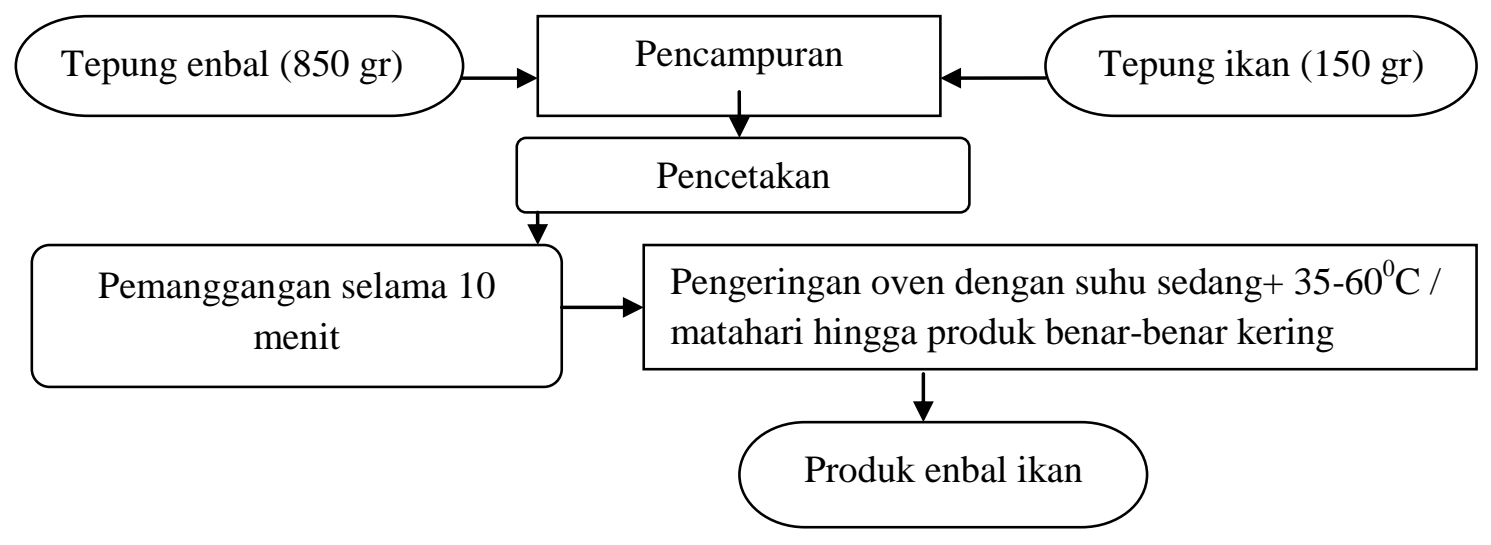

\section{HASIL PENELITIAN DAN PEMBAHASAN}

\section{Tahap awal (Pendekatan Mitra)}

1. Kegiatan tahap awal dalam pengabdian ini yaitu berupa pertemuan dengan kedua mitra yaitu Mawar dan Dahlia. Dalam pertemuan ini kami menyampaikan keinginan kami untuk membantu kedua kelompok dalam menjawab semua permasalahan yang dialami mereka. Lanjut dari pertemuan tersebut juga membicarakan tentang persiapan dan rencana kegiatan yang akan dilakukan kedua kelompok. Dari hasil kegiatan pertemuan tersebut, terlihat adanya permasalahan yang dihadapi yaitu kurangnya ketrampilan dalam diversifikasi olahan enbal, manajemen usaha, dan keuangan (buku kas), penyediaan peralatan, serta perluasan jaringan dan strategi pemasaran. Para ibu tersebut membutuhkan informasi pengetahuan dan teknologi sehingga dapat menambah ketrampilan dalam mengelola dan menjual produk yang dimiliki. Melihat potensi laut yang sangat kaya produksi ikannya maka lewat kegiatan IbM ini juga akan dilakukan olahan enbal yang baru yaitu enbal ikan dimana adanya penambahan tepung ikan sebagai sumber protein pada enbal. Kegiatan IbM in dirancang dan dikemas beberapa kegiatan meliputi penyuluhan dan pelatihan manajemen usaha dan pengelolaan keuangan, sistem pengemasan yang baik, pembuatan enbal ikan, strategi pemasaran dan upaya memperluas jaringan pemasaran, sanitasi dan hygiene serta pemberian peralatan pembuatan tepung ikan. 


\section{Kegiatan Penyuluhan dan Pelatihan}

\section{A. Penyuluhan}

Kegiatan penyuluhan dan pelatihan dilakukan secara bersama-sama dengan kedua mitra yaitu Mawar dan Dahlia. Materi yang diberikan oleh tim dibagi atas masing-masing bidang ilmu yaitu Ir. B.B Tumiwa, M.Si memberikan materi:

1. Manajemen usaha dan pengelolaan keuangan meliputi manajemen usaha, kiat kiat sukses berwirausaha serta pengelolaan keuangan dan sistem pembukuan yang baik,

2. Strategi pemasaran dan upaya memperluas jaringan pemasaran meliputi strategi pemasaran, upaya perluasan jaringan pemasaran dan teknik promosi.

Elizabeth J. Tapotubun, S.Pi, M.Si memberikan materi:

1. Sistem pengemasan yang baik meliputi manfaat kemasan dan label, memilih kemasan yang baik, teknik pengemasan dan pelabelan.

2. Materi pembuatan enbal ikan serta keamanan pangan berupa bahaya mengkonsumsi pangan yang tidak aman serta sanitasi dan higiene.

3. Kedua teknisi yang bersama - sama dalam kegiatan IbM ini membantu pada saat penyuluhan dan pelatihan yang dilakukan

\section{B. Pelatihan Pembuatan Enbal Ikan}

Tepung ikan dan tepung enbal yang telah siap kemudian di timbang dengan berat masing-masing untuk tepung ikan 150 gr dan tepung enbal 850 gr. Kedua tepung tersebut kemudian dicampur sampai homogen dan diletakan dalam cetakan yang terbuat dari alumunium. Cetakan yang telah berisi adonan tepung enbal dengan tepung ikan kemudian dibakar di atas tungku perapian selama \pm 10 menit dengan cetakan yang tertutup agar proses pembakaran berjalan sempurna dan adonan matang secara merata. Enbal ikan yang telah masak kemudian diambil dan dikeringkan menggunakan oven atau dijemur dibawah sinar matahari sampai produk benar-benar kering. Enbal ikan yang telah siap kemudian dikemas.

\section{Pelatihan Pembuatan Buku Kas dan Cap produksi}

Dalam kegiatan IbM ini juga dilakukan pelatihan pembuatan buku kas yaitu pembuatan buku kas usaha yang sebelumnya lewat materi penyuluhan diajarkan perhitungan debit dan kredit serta keuntungan usaha yang di dapatkan.

Cap produksi kedua mitra juga di desain dan dibuat berdasarkan keinginan kedua mitra dengan berpatokan arti dan ciri tersendiri dan yang merupakan legalitas usaha sehingga dengan sendirinya membantu mitra dalam berproduksi keluar.

\section{Pemberian Bantuan Peralatan Tepung Ikan}

Kedua mitra yakni Mawar dan Dahlia diberikan bantuan peralatan tepung ikan untuk menunjang pengelolaan usaha enbal ikan. Pemberian bantuan peralatan ini berupa: blender, kompor, oven, porna cetakan, ayakan, Loyang plastic, nyiru, plastik kemasan dan sealer kemasan.

Pemberian bantuan peralatan tepung ikan ini diberikan oleh tim IbM kepada kedua mitra dengan harapan dapat lebih memperlancar produksi tepung ikan sehingga bisa mengembangkan usaha enbal ikan menjadi lebih baik lagi.

\section{E. Evaluasi dan Pendampingan}

Pada tahap evaluasi, kelompok usaha Mawar dan Dahlia ini telah dapat mempraktekkan materi yang diberikan dalam penyuluhan dan pelatihan baik praktek 
membuat buku kas, pengadaan cap produksi kelompok, praktek teknik mengemas yang baik dengan pelabelan yang benar dan menarik, praktek pengolahan pembuatan tepung ikan, penerapan sanitasi dan hygiene dan cara promosi.

Pendampingan telah dilakukan setelah pelaksanaan kegiatan penyuluhan dan pelatihan. Hasil pengamatan tim bahwa strategi pemasaran dan promosi yang dilakukan memberikan hasil yang memuaskan dengan banyaknya permintaan enbal ikan baik yang datang dari daerah Kabupaten Maluku Tenggara, Kota Tual maupun permintaan dari luar daerah seperti Ambon, Makassar, Bali, Surabaya dan Jakarta serta beberapa Negara luar seperti Belanda dan Australia.

\section{KESIMPULAN}

Ipteks bagi Masyarakat (IbM) Ohoi Wain yang terdiri dari Mitra Mawar dan

Dahlia meliputi :

1. Penyuluhan dan pelatihan manajemen usaha dan pengelolaan keuangan, strategi pemasaran, sistem pengemasan, pembuatan enbal ikan, pembuatan buku kas dan cap produksi.

2. Pemberian bantuan peralatan tepung ikan

3. Evaluasi dan pendampingan berkelanjutan

\section{DAFTAR PUSTAKA}

Annafi FA. 2009. Proses Pengolahan Tepung Ikan dengan Metode Konvensional sebagai Usaha Pemanfaatan Limbah Perikanan. Makalah Seminar. Universitas Gadjah Mada Yogyakarta.

Riry J, Lawalata V. N, Tapotubun E. J, Far-Far R.A. 2013. Mutu Organoleptik Produk Enbal Fortifikasi (Mkanan Tradisional Kepulauan Ke ) Ditinjau Dari Daya Terima Konsumen. Jurnal Masyarakat Pengolahan Hasil Perikanan Indonesia (JPHPI). Volume 16 Nomor 3

Riry J., Tapotubun E. J., Tapotubun A.M. 2018. Nutrien Content and Shelf Life of Best Fortified Enbal From Kei Islands Added with Fish Meal and Sweet Potato Leaf Flour. International Journal Of ChemTech Research. CODEN (USA) : IJCRGG, ISSN (Online): 2455-9555. Vol. 11No.06, pp 232-238.

Sentot Harman Glendoh, 2001. Pembinaan dan Pengembangan Usaha Kecil. Jurnal Manajemen \& Kewirausahaan Vol. 3, No. 1, Maret 2001: 1 - 13.

Tapotubun, E., 2012. Kandungan Gizi Dan Masa Simpan Makanan Tradisional "Enbal "Asal Kepulauan Kei dengan Penambahan Tepung Ikan Layang. Thesis Sekolah Pascasarjana Institut Pertanian Bogor. 